\title{
Investigation on Hot Corrosion Behaviour of Inconel 625 and Incoloy 800H Superalloys with YSZ-Thermal Barrier Coating Under High-Temperature Environment for Bioreactor Applications
}

\author{
M. Kamatchi Hariharan $\left(\mathbb{D},{ }^{1}\right.$ A. Anderson $\left(\mathbb{D},{ }^{2}\right.$ T. R. Praveenkumar $(\mathbb{D})^{3}$ \\ and Endalkachew Mosisa ${ }^{4}$ \\ ${ }^{1}$ School of Mechanical Engineering, Sathyabama Institute of Science \& Technology, Chennai, India \\ ${ }^{2}$ School of Mechanical Engineering, Sathyabama Institute of Science \& Technology, Chennai, India \\ ${ }^{3}$ Department of Construction Technology and Management, Wollega University, Nekemte, Ethiopia \\ ${ }^{4}$ Department of Mechanical Engineering, Wollega University, Nekemte, Ethiopia
}

Correspondence should be addressed to A. Anderson; chrisson100@gmail.com and T. R. Praveenkumar; pravirami@gmail.com

Received 2 December 2021; Revised 19 January 2022; Accepted 22 January 2022; Published 24 February 2022

Academic Editor: Palanivel Velmurugan

Copyright (c) 2022 M. Kamatchi Hariharan et al. This is an open access article distributed under the Creative Commons Attribution License, which permits unrestricted use, distribution, and reproduction in any medium, provided the original work is properly cited.

\begin{abstract}
Thermal energy storage is one of the promising technologies in the modern era for balancing the peak power demand without emitting much emission. Molten-salt technology plays a dominant role among the varieties of thermal energy storage systems. The difficulty in storing the molten-salt technology requires a storage material with high temperature, corrosion, and oxidation resistance properties. The nickel-based superalloys such as Inconel 625 and Incoloy $800 \mathrm{H}$ possess the desired properties to be used as a storage material for the molten salts. In this present work, the Incoloy $800 \mathrm{H}$ and Inconel 625 superalloy specimens were taken up for investigation. The specimens were coated with yttria-stabilized zirconia as a thermal barrier coating using a plasma spray process. The sodium chloride and potassium chloride molten salts with a weight fraction of $7: 3$ have been taken with both uncoated and YSZ-coated specimens, and specimens were heated up to $1000^{\circ} \mathrm{C}$ approximately. The specimens were heated for different hours such as 8, 12, and 16 hours, respectively. The increase in heating time also results in the increase in the tensile property of the specimens. The mechanical testing, such as tensile test and hardness test, was performed to comprehend the mechanical properties. Scanning electron microscope images and X-ray diffraction analysis were made to study the microstructural properties and the corrosion resistance property. From the test results, YSZ-coated specimens possess high corrosion resistance and high mechanical strength compared to the uncoated specimens.
\end{abstract}

\section{Introduction}

Superalloys are an alloy with a high-melting point capability. It includes the outstanding mechanical strength, thermal deformation resistance, good surface stability, and corrosion or oxidation resistance. Super alloys are mostly formed as one single crystal, which increases creep resistance while the grain boundaries may provide strength at low temperatures. Inconel 625 is used for its high strength, excellent fabricability (includ- ing joining), and outstanding corrosion resistance. Its service temperatures range from cryogenic to $1800^{\circ} \mathrm{F}\left(982^{\circ} \mathrm{C}\right)[1-3]$.

Similarly, Incoloy $800 \mathrm{H}$ possesses chemical properties for high-temperature strength and resistance to oxidation, carburization, and other high-temperature corrosion. Incoloy $800 \mathrm{H}$ has high nickel and chromium content, and this helps in resisting oxidation. A protective surface oxide is formed due to the presence of chromium, and nickel will provide the additional protection during continuous exposure 


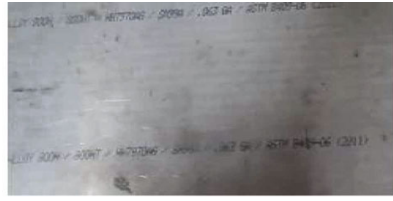

(a)

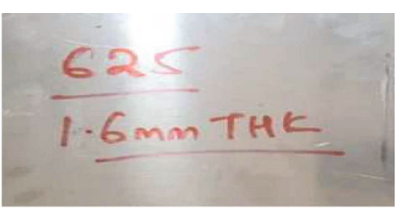

(b)

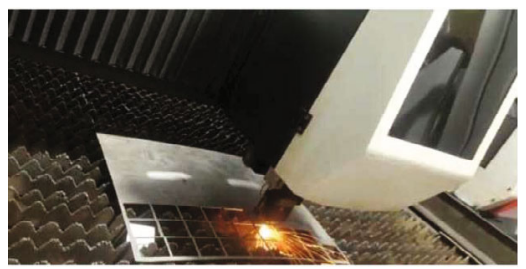

(c)

Figure 1: (a) The Incoloy 800H sheet, (b) Inconel 625 sheet, and (c) laser beam machining.

to high temperature $[4,5]$. Thermal barrier coatings which are usually coated in metal surfaces find their application in hightemperature environment such as gas turbines and aero engine parts $[18,20]$. The ceramic coatings like aluminum oxide, silicon oxide, and zirconia are the commonly used coatings, whereas zirconia possesses high-melting point and low coefficient of thermal expansion. Yttria-stabilized zirconia is one of the kinds of TBC applied in Inconel 625 and Incoloy $800 \mathrm{H}$ with the aid of bond coat material of NiCoAlY. All these TBC can be coated with the bond coat with the different substrates using the plasma spray coating process [6-8]. The molten salts are available in solid form in general, and their solid form changes to liquid phase when exposed to high temperature. Among the wide spread of molten salts, with frequently used eutectic mixture of $7: 3$, sodium chloride and potassium chloride molten salts were taken for analysis. Both salts are available in solid phase, and solid salts change to liquid phase when exposed to high temperature more than $770^{\circ} \mathrm{C}$. Due to this enhanced property, the molten-salt technology is rising the efficiency and storage capacity of concentrated solar power plants while falling solar thermal energy costs. The molten salt is used as a heat-transfer fluid (HTF) and thermal energy storage (TES) in solar power plants [9-12]. Several other methods may be employed to improve the properties of any composite materials $[13,14]$.

In this present work, Inconel 625 and Incoloy $800 \mathrm{H}$ have been taken up for the investigation. The base materials were coated with YSZ as a TBC coating using the plasma spray process. Both coated and uncoated substrates were heated with sodium and potassium chloride up to $1000^{\circ} \mathrm{C}$ in a muffle furnace for 8,12 , and 16 hours, respectively. The tensile test and hardness test were conducted on the heated specimens, and the mechanical properties were compared. The SEM images were taken, and XRD analysis was done for performing the microstructural analysis [15-17].

\section{Materials and Methods}

The Inconel 625 and Incoloy $800 \mathrm{H}$ sheets of $1.6 \mathrm{~mm}$ thickness have been used, and the following test specimens were prepared as per ASTM standard dimensions. The materials used for this investigation can be seen from Figures 1(a) and 1(b).

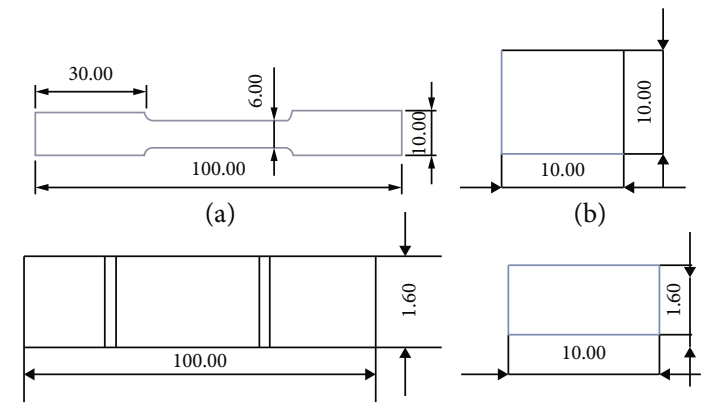

(c)

(d)

Figure 2: (a) Top view of the tensile specimen. (b) Top view of the SEM and XRD specimen. (c) Front view of the tensile specimen. (d) Front view of the SEM and XRD specimen.

The sheets were cut into required size and dimensions with a laser beam machining technique with reference to Figure 1(c). The material composition was tested using "OES Foundry Spectro-Analyzer". The tensile test specimens as given in Figures 2(a) and 2(c) were prepared to know the yield strength, ultimate tensile strength, and \% of elongation. All the dimensions shown in the figures are in millimeters. The SEM and XRD characterization study specimens are shown in Figures 2(b) and 2(d) in the dimension of $10 \times 10 \mathrm{~mm}$, respectively. All specimens, such as tensile test and SEM and XRD, were coated with yttria-stabilized zirconia as the thermal barrier coating to enhance the temperature resistance and corrosion resistance properties of the base substrate. 150 microns of YSZ coating thickness was used with the bond coat material of NiCoAlY. The coated specimens of both YSZ and Inconel 625 can be seen in Figure 3(a), whereas YSZ and Incoloy $800 \mathrm{H}$ specimens can be seen in Figure 3(b).

The specimens coated with YSZ and uncoated specimens were heated up to $1000^{\circ} \mathrm{C}$ in a muffle furnace for 8,16 , and 24 hours with the sodium and potassium chloride molten salts with a weight fraction of $70: 30$ grams, respectively. Before heating, the specimens were cleaned with acetone solution to remove the any impurities on the surface material. The heated specimens were taken, and salt crystals were removed. The polished specimens after the heating process 


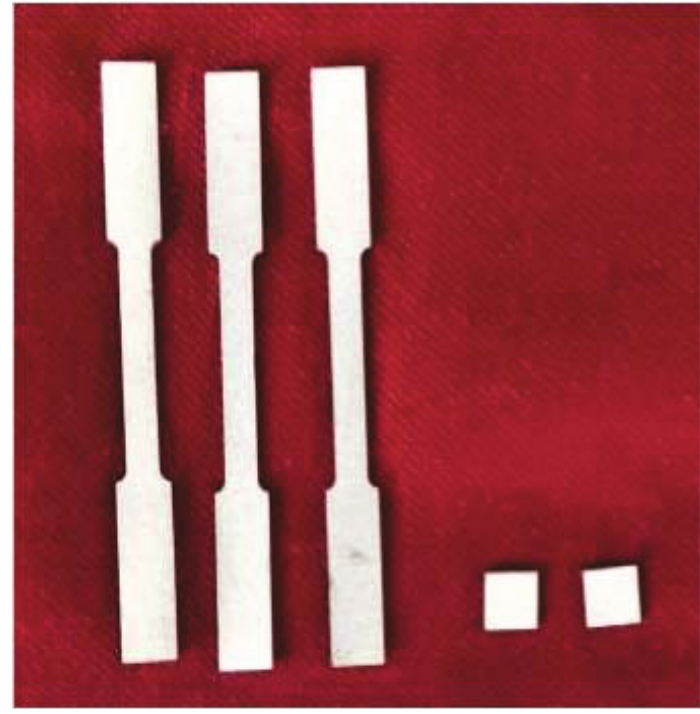

(a)

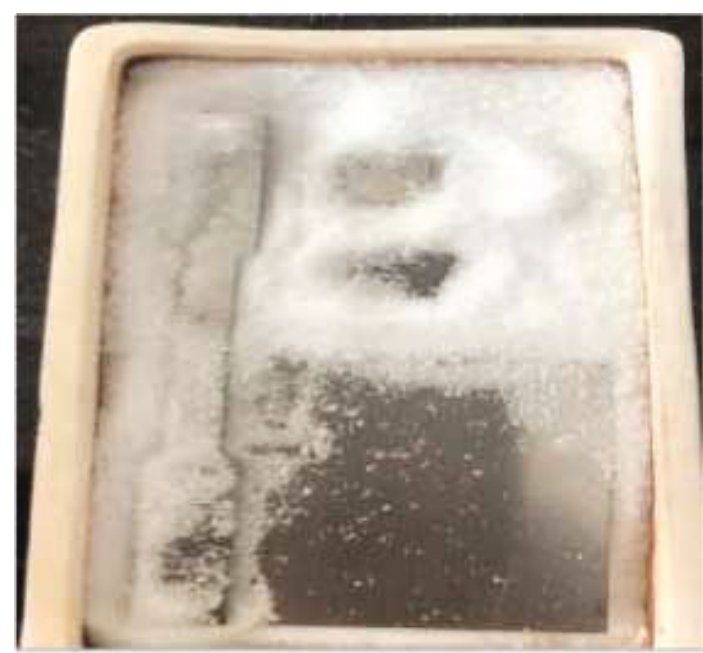

(c)

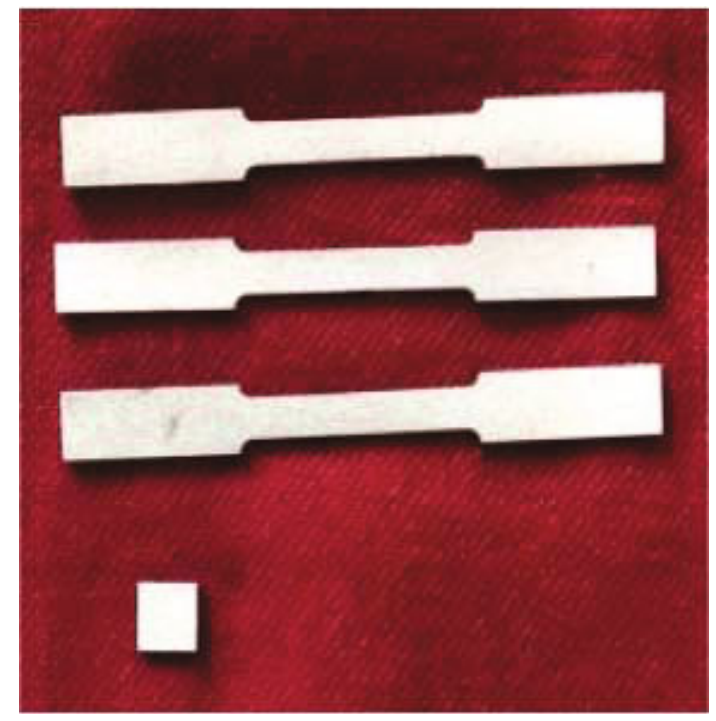

(b)

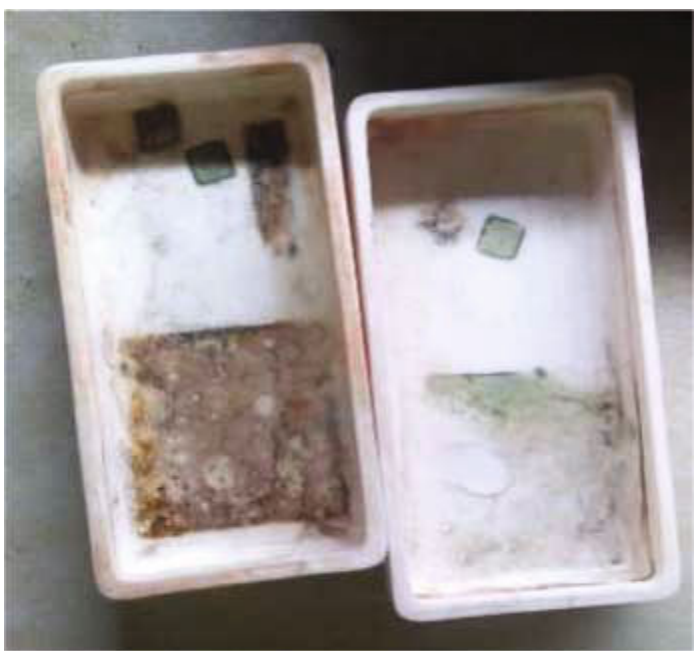

(d)

FIGURE 3: (a) YSZ-Inconel 625-coated specimens. (b) YSZ-Incoloy $800 \mathrm{H}$-coated specimens. (c) Specimens before heating. (d) Specimens after heating.

were used for mechanical testing and characterization study. The specimens before the heating process can be seen from Figure 3(c), and those after heating can be seen from Figure 3(d).

\section{Results and Discussion}

After the heating process of specimens with different hours, the specimens were tested with the tensile test and hardness test. The results have been discussed for the comparative analysis of the yield strength, ultimate tensile strength, and $\%$ of elongation.

3.1. Inconel 625: Tensile Test Results. The tensile test has been carried out for the different specimens with the aid of universal testing machine. The unheated/raw specimens of uncoated Inconel 625 specimen result in yield strength of $614 \mathrm{MPa}$, ultimate tensile strength of $970 \mathrm{MPa}$, and \% of elongation of 42.50 in $25 \mathrm{~mm}$ gauge length. The unheated YSZ-coated specimens result in yield strength of $624 \mathrm{MPa}$, ultimate tensile strength of $1015 \mathrm{MPa}$, and \% of elongation of 47.0 in $25 \mathrm{~mm}$ gauge length. The influence of YSZ coating on the Inconel 625 specimens increases by $1.60 \%$ in yield strength and $4.43 \%$ in ultimate tensile strength as shown in Figure 4 . The tensile test conducted on 8-hour-heated specimens result in yield strength of $243 \mathrm{MPa}$, ultimate tensile strength of $551 \mathrm{MPa}$, and \% of elongation of 38.00 in $25 \mathrm{~mm}$ gauge length. The 8-hour-heated YSZ-coated specimens result in yield strength of $334 \mathrm{MPa}$, ultimate tensile strength of $568 \mathrm{MPa}$, and \% of elongation of 32.0 in $25 \mathrm{~mm}$ gauge length. The effect of YSZ coating on the 8-hour-heated Inconel 625 specimens increases by $27.24 \%$ in yield strength and $2.99 \%$ in ultimate tensile strength as shown in Figure 5.

The tensile test conducted on 12-hour-heated specimens results in yield strength of $223 \mathrm{MPa}$, ultimate tensile strength of $472 \mathrm{MPa}$, and \% of elongation of 29.50 in $25 \mathrm{~mm}$ gauge 


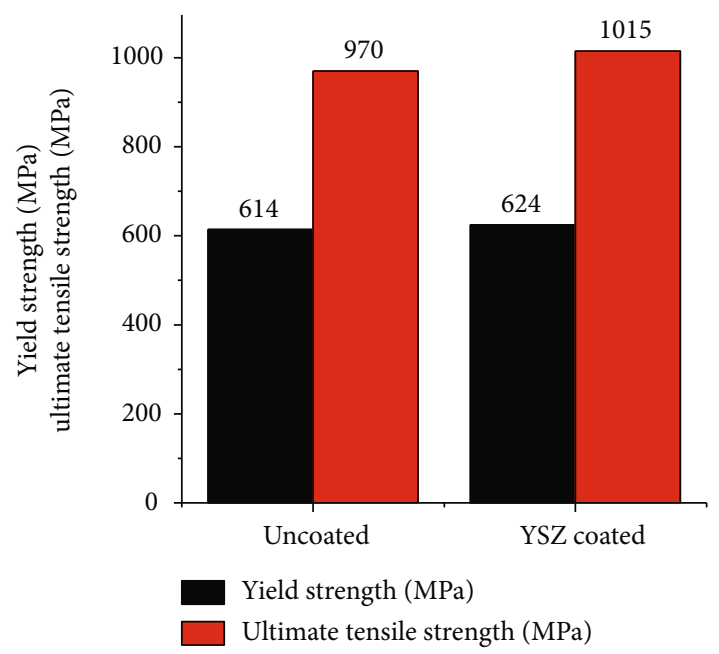

Figure 4: Inconel 625 (unheated specimen) mechanical test result.

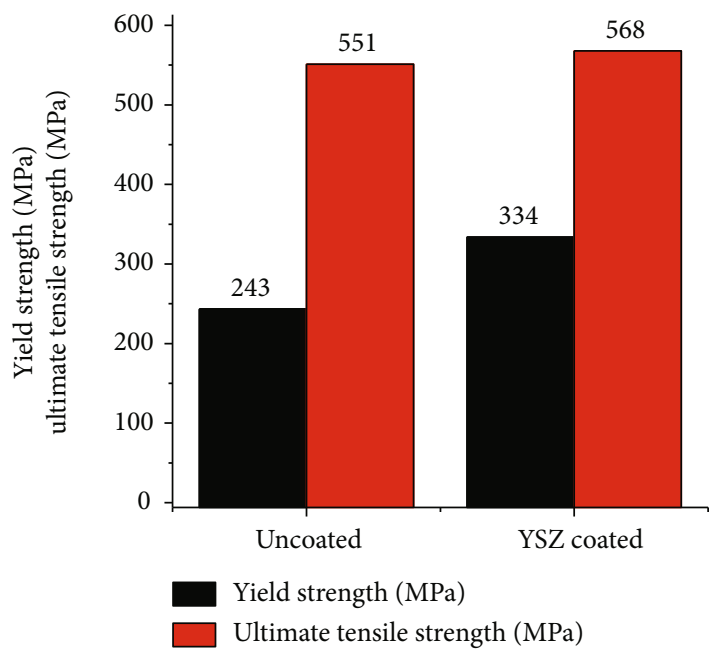

FIGURE 5: Inconel 625 (8-hour-heated specimen) mechanical test result.

length. The 12-hour-heated YSZ-coated specimens result in yield strength of $310 \mathrm{MPa}$, ultimate tensile strength of $577 \mathrm{MPa}$, and \% of elongation of 27.50 in $25 \mathrm{~mm}$ gauge length. The result of YSZ coating on the 12-hour-heated Inconel 625 specimens increases by $28.06 \%$ in yield strength and $18.19 \%$ in ultimate tensile strength as shown in Figure 6. With reference to Figure 7, the tensile test conducted on 16-hour-heated specimens results in yield strength of $166 \mathrm{MPa}$, ultimate tensile strength of $403 \mathrm{MPa}$, and \% of elongation of 21.50 in $25 \mathrm{~mm}$ gauge length. The 16-hour-heated YSZ-coated specimens result in yield strength of $306 \mathrm{MPa}$, ultimate tensile strength of $572 \mathrm{MPa}$, and \% of elongation of 31.50 in $25 \mathrm{~mm}$ gauge length. The result of YSZ coating on the 16-hour-heated Inconel 625 specimens increases by $45.75 \%$ in yield strength and $29.54 \%$ in ultimate tensile strength. Thus, the influence of YSZ coating results in increase in the yield strength and ultimate tensile strength for all Inconel 625 specimens. The increase in heating time also results in increase in the tensile property of the specimens [19].

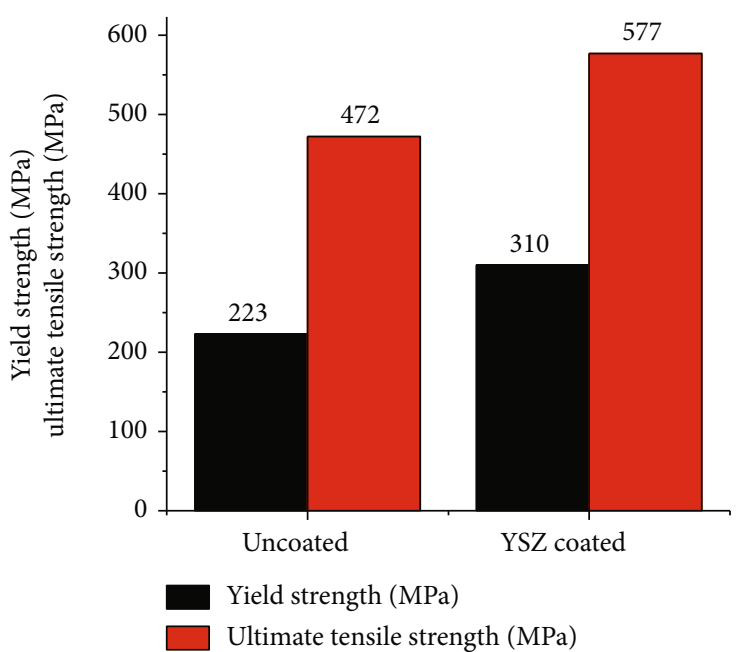

FIGURE 6: Inconel 625 (12-hour-heated specimens) mechanical test result

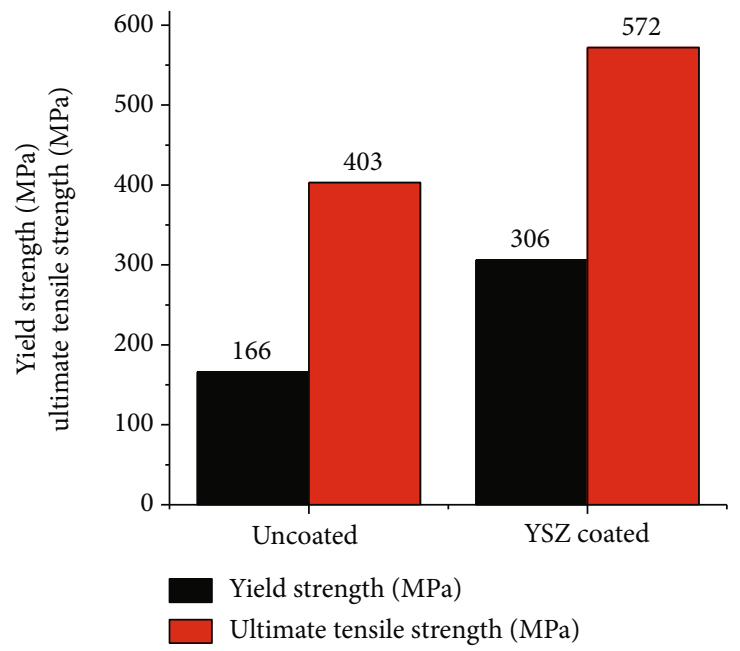

FIgURE 7: Inconel 625 (16-hour-heated specimens) mechanical test results.

3.2. Incoloy 800H: Tensile Test Results. Similar to the Inconel 625 , the tensile test for Incoloy $800 \mathrm{H}$ has been carried out for the different specimens. The unheated/raw specimens of uncoated Incoloy $800 \mathrm{H}$ specimens result in yield strength of $291 \mathrm{MPa}$, ultimate tensile strength of $593 \mathrm{MPa}$, and \% of elongation of in $25 \mathrm{~mm}$ gauge length. The unheated YSZcoated specimens result in yield strength of $312 \mathrm{MPa}$, ultimate tensile strength of $606 \mathrm{MPa}$, and \% of elongation of 41.50 in $25 \mathrm{~mm}$ gauge length. The influence of YSZ coating on the Incoloy $800 \mathrm{H}$ specimens increases by $6.73 \%$ in yield strength and $2.14 \%$ in ultimate tensile strength as shown in Figure 8. With reference to Figure 9, the tensile test conducted on 8-hour-heated Incoloy $800 \mathrm{H}$ specimens results in yield strength of $263 \mathrm{MPa}$, ultimate tensile strength of $552 \mathrm{MPa}$, and \% of elongation of 30.50 in $25 \mathrm{~mm}$ gauge length. The 8-hour-heated YSZ-coated specimens result in yield strength of $292 \mathrm{MPa}$, ultimate tensile strength of $566 \mathrm{MPa}$, and \% of elongation of 38.0 in $25 \mathrm{~mm}$ gauge length. The effect of YSZ coating on the 8-hour-heated 


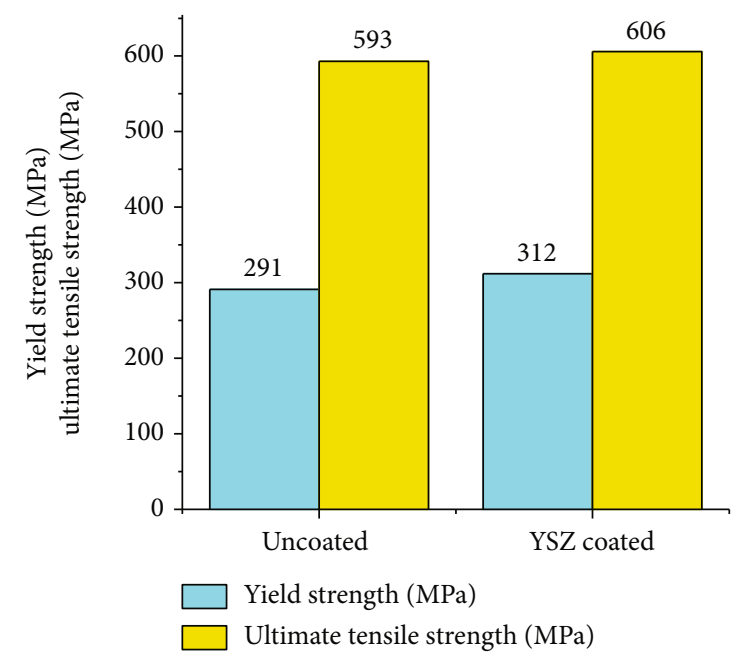

FIGURE 8: Incoloy $800 \mathrm{H}$ (unheated specimens) mechanical test results.

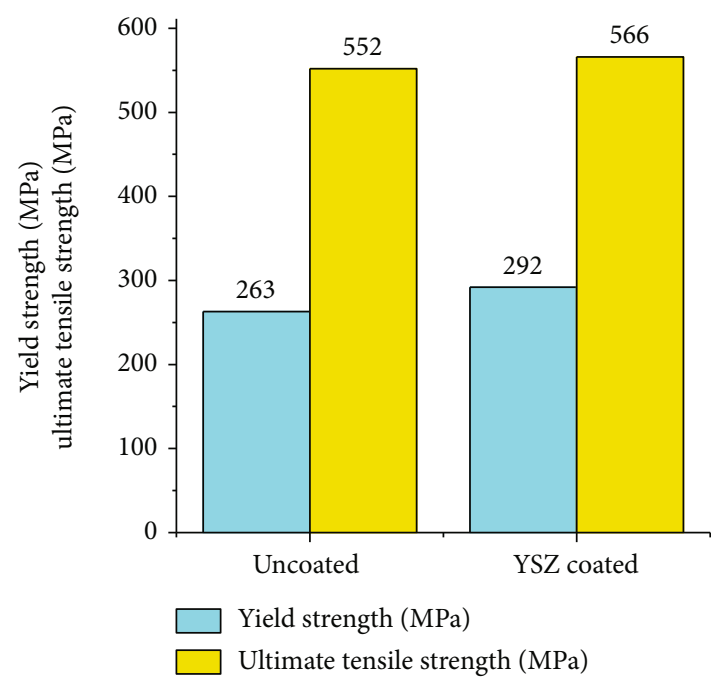

FIGURE 9: Incoloy $800 \mathrm{H}$ (8-hour-heated specimens) mechanical test results.

Incoloy $800 \mathrm{H}$ specimens increases by $9.93 \%$ in yield strength and $2.47 \%$ in ultimate tensile strength. The tensile test conducted on 12-hour-heated specimens results in yield strength of $247 \mathrm{MPa}$, ultimate tensile strength of $486 \mathrm{MPa}$, and \% of elongation of 29.00 in $25 \mathrm{~mm}$ gauge length. The 12-hour-heated YSZ-coated specimens result in yield strength of $267 \mathrm{MPa}$, ultimate tensile strength of $499 \mathrm{MPa}$, and $\%$ of elongation of 36.50 in $25 \mathrm{~mm}$ gauge length. The result of YSZ coating on the 12-hour-heated Incoloy $800 \mathrm{H}$ specimens increases by $7.49 \%$ in yield strength and $2.60 \%$ in ultimate tensile strength as shown in Figure 10.

Tensile test conducted on 16-hour-heated specimens result in yield strength of $229 \mathrm{MPa}$, ultimate tensile strength of $301 \mathrm{MPa}$ and a \% of 28.50 elongation in $25 \mathrm{~mm}$ gauge length. The 12-hour-heated YSZ-coated specimens result in yield strength of $253 \mathrm{MPa}$, ultimate tensile strength of $340 \mathrm{MPa}$, and \% of 38.50 elongation in $25 \mathrm{~mm}$ gauge length. The result of YSZ coating on the 8-hour-heated Incoloy

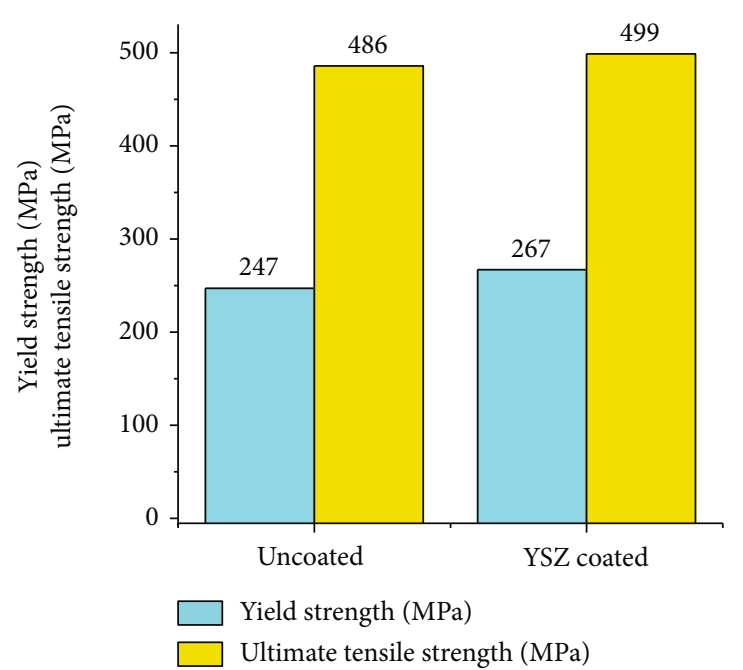

FIgURE 10: Incoloy $800 \mathrm{H}$ (12-hour-heated specimens) mechanical test results.

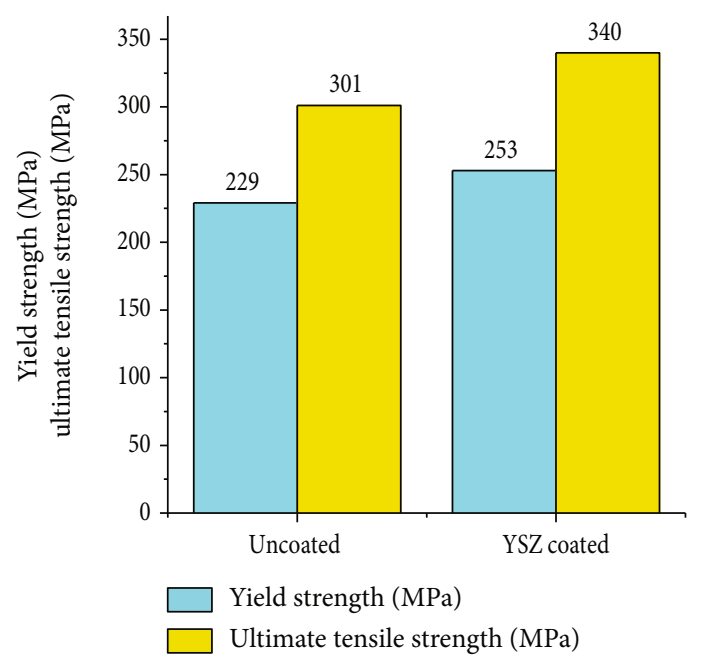

FIgURE 11: Incoloy $800 \mathrm{H}$ (16-hour-heated specimens) mechanical test results.

$800 \mathrm{H}$ specimens increases by $9.48 \%$ in yield strength and $11.47 \%$ in ultimate tensile strength as shown in Figure 11.

The influence of YSZ coating on the Incoloy $800 \mathrm{H}$ superalloy increases the tensile property of the specimen and influence of heating also resulted in increase in yield strength and ultimate tensile strength. Based on the results obtained, it can be suggested that, influence of YSZ thermal barrier coating increases the yield strength and ultimate tensile strength for both Inconel 625 and Incoloy $800 \mathrm{H}$ specimens.

3.3. Hardness Test Results. The hardness value for all the heated specimens of both Inconel 625 and Incoloy $800 \mathrm{H}$ were measured using a Vickers hardness tester.

The hardness values for uncoated Inconel 625 specimens were gradually decreased for different hours of heating process. The hardness value for uncoated and unheated specimen decreased from $171.9 \mathrm{HV}$ to $146.3 \mathrm{HV}$ after 16 hours of heating as shown in Figure 12. With reference to Figure 13, for YSZ-Inconel 


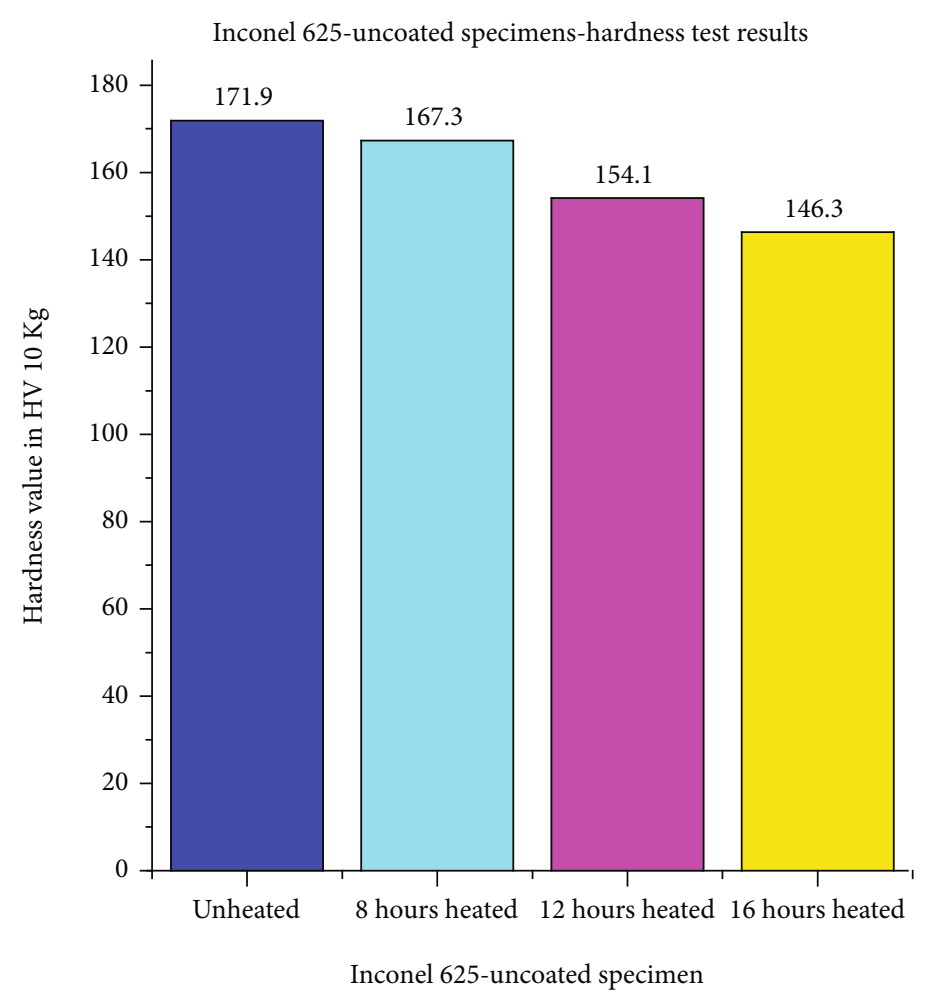

Figure 12: Inconel 625 (uncoated coated specimens) hardness test results.

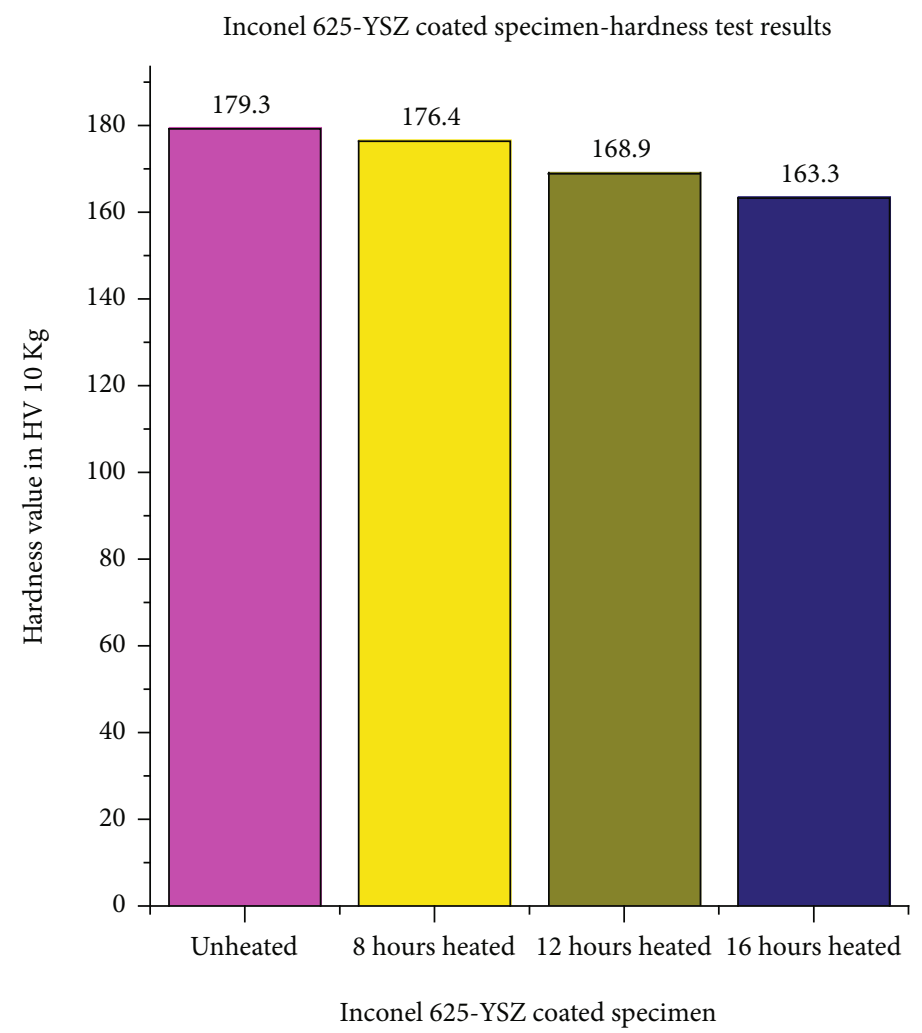

Figure 13: Inconel 625 (YSZ-coated specimens) hardness test results. 


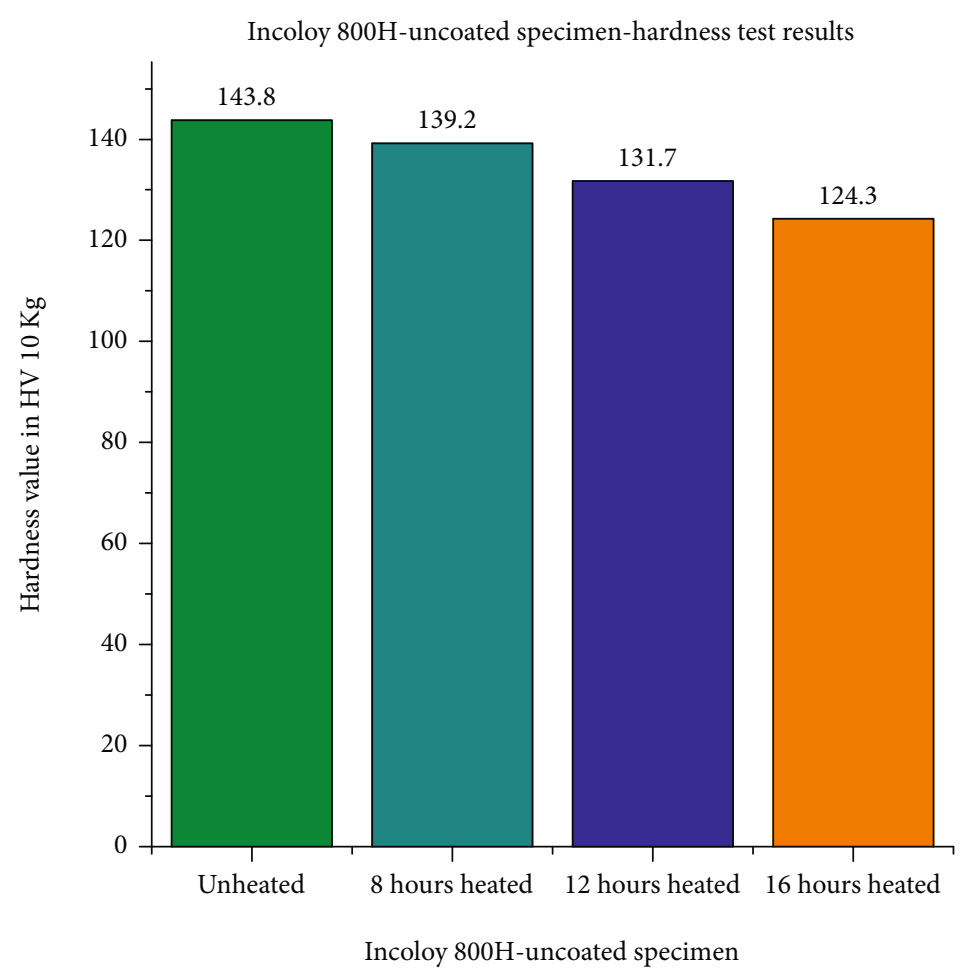

Figure 14: Incoloy $800 \mathrm{H}$ (uncoated specimens) hardness test results.

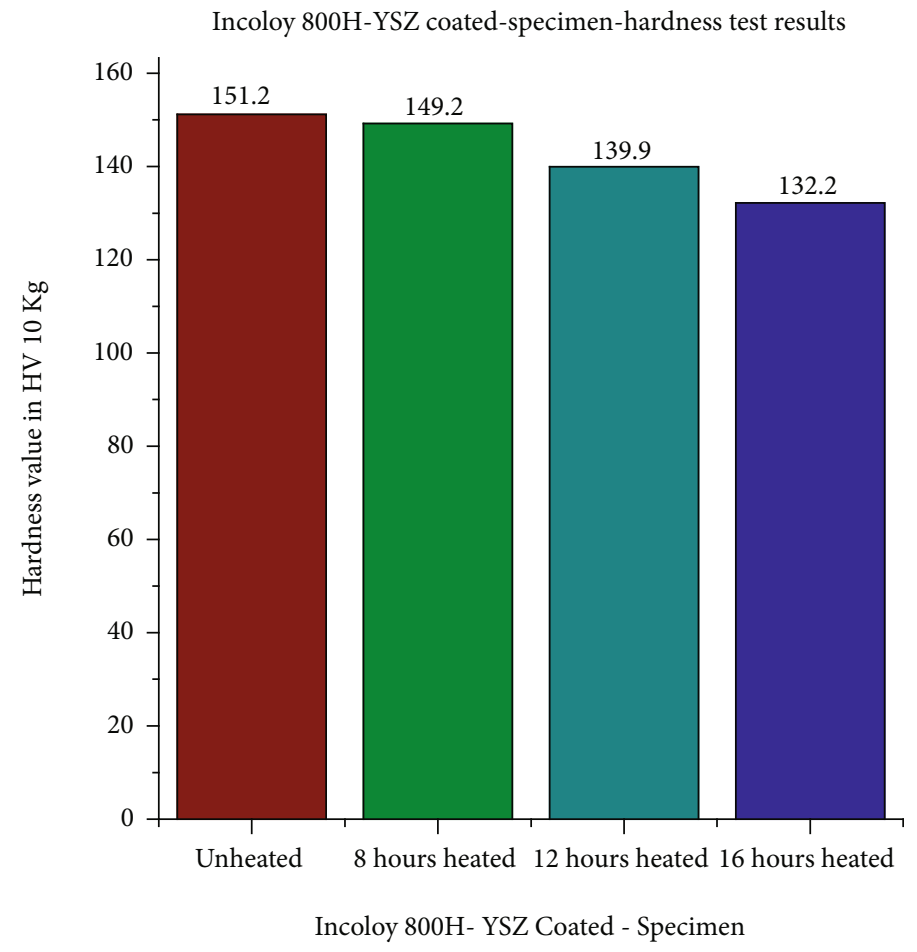

Figure 15: Incoloy $800 \mathrm{H}$ (YSZ-coated specimens) hardness test results.

625-coated specimens the hardness value decreased from $179.3 \mathrm{HV}$ to $163.3 \mathrm{HV}$ after 16 hours of heating. The overall reduction of hardness value was found to be $14.89 \%$ for uncoated Inconel 625 specimens and $8.92 \%$ for YSZ- coated specimens. The hardness value for uncoated Incoloy $800 \mathrm{H}$ specimens were gradually decreased for different hours of heating process. The hardness value for Incoloy $800 \mathrm{H}$ uncoated and unheated specimen decreased from 


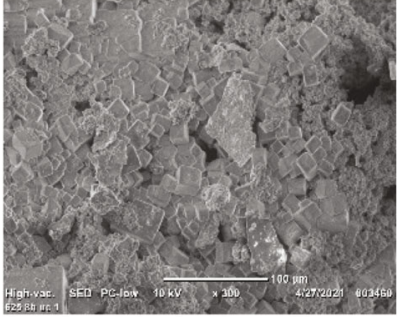

(a)

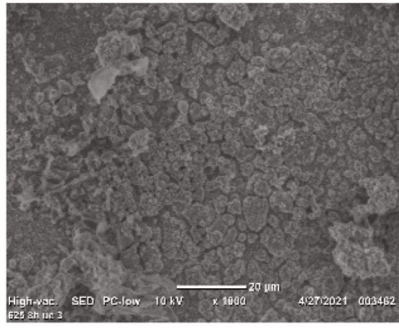

(d)

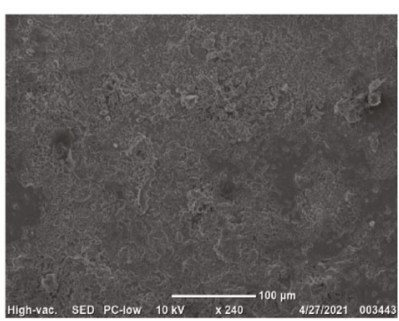

(b)

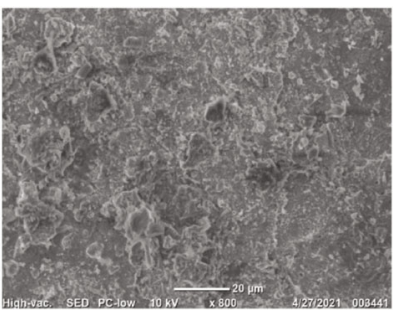

(e)

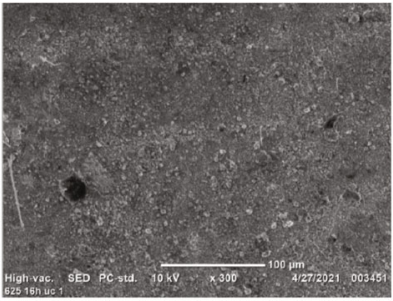

(c)

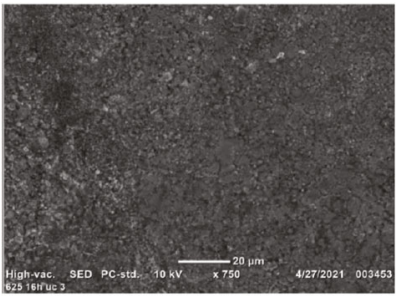

(f)

FIGURE 16: SEM images of Inconel 625 specimens. (a) Uncoated 8-hour-heated 300x magnification. (b) Uncoated 12-hour-heated 300x magnification. (c) Uncoated 16-hour-heated 300x magnification. (d) Uncoated 8-hour-heated 300x magnification. (e) Uncoated 12-hourheated 300x magnification. (f) Uncoated 16-hour-heated 300x magnification.

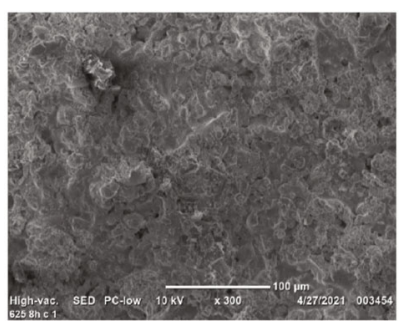

(a)

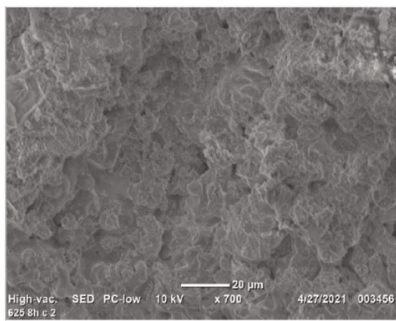

(d)

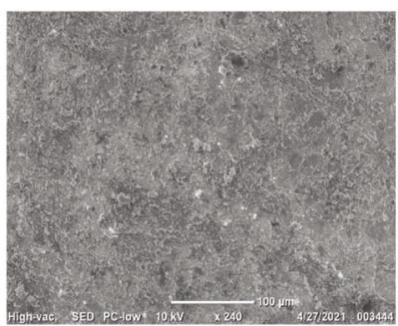

(b)

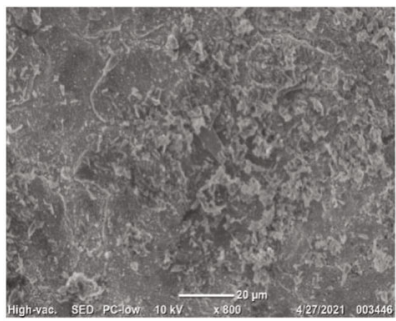

(e)

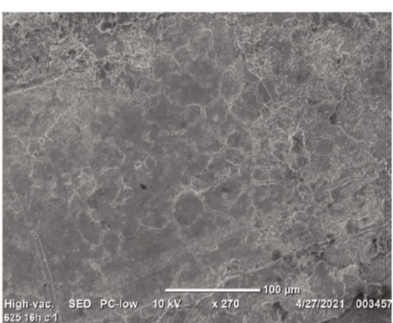

(c)

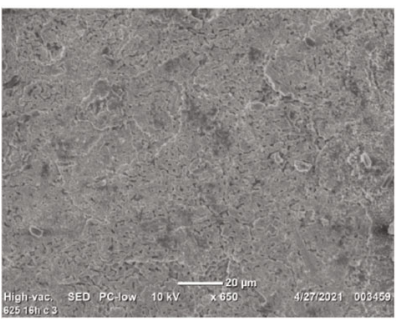

(f)

FIGURE 17: SEM images of Inconel 625 specimens. (a) YSZ-coated 8-hour-heated 300x magnification. (b) YSZ-coated 12-hour-heated 300x magnification. (c) YSZ-coated 16-hour-heated 300x magnification. (d) YSZ-coated 8-hour-heated 300x magnification. (e) YSZ-coated 12hour-heated 300x magnification. (f) YSZ-coated 16-hour-heated 300x magnification.

143.8 $\mathrm{HV}$ to $124.3 \mathrm{HV}$ after 16 hours of heating as shown in Figure 14. With reference to Figure 15, for YSZ-coated specimens the hardness value decreased from $151.2 \mathrm{HV}$ to 132.2 HV after 16 hours of heating. The overall reduction of hardness value was found to be $13.56 \%$ for uncoated Incoloy $800 \mathrm{H}$ specimens and $12.56 \%$ for YSZ-coated specimens. The obtained values indicating that, influence of YSZ coating results in the increase in hardness in both Inconel 625 and Incoloy $800 \mathrm{H}$ specimens, whereas the influence of high aggressive environment resulted in decrease in the hardness value for both Inconel 625 and Incoloy $800 \mathrm{H}$ specimens.

3.4. Microstructural Analysis. The scanning electron microscope images were taken for both uncoated and YSZcoated specimens which is heated for different hours. The images were taken under different magnification for to have clear analysis. With reference to Figures 16 and 17, the SEM 


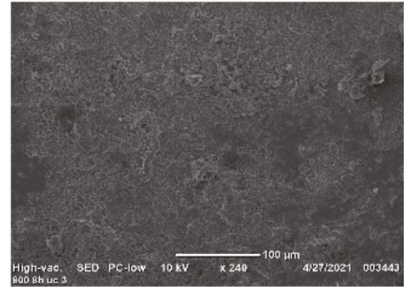

(a)

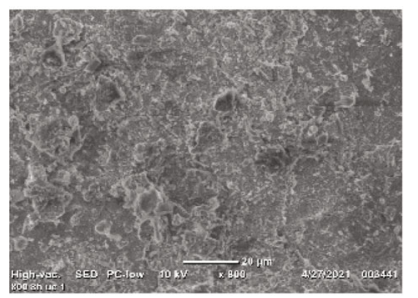

(d)

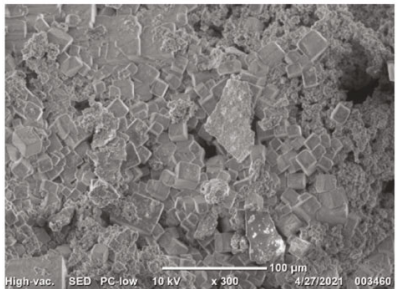

(b)

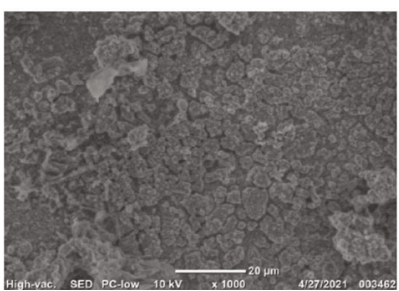

(e)

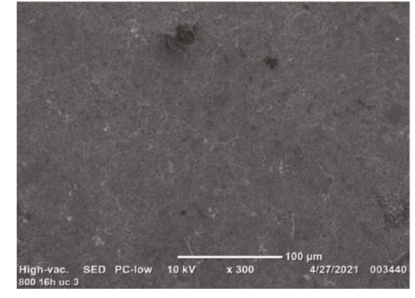

(c)

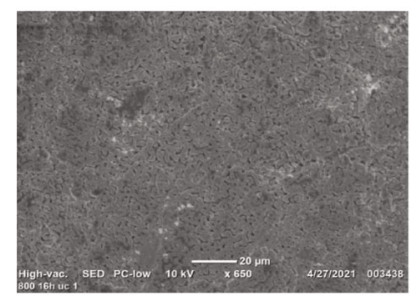

(f)

FIgURE 18: SEM images of Incoloy $800 \mathrm{H}$ specimens. (a) Uncoated 8-hour-heated 300x magnification. (b) Uncoated 12-hour-heated 300x magnification. (c) Uncoated 16-hour-heated 300x magnification. (d) Uncoated 8-hour-heated 300x magnification. (e) Uncoated 12-hourheated 300x magnification. (f) Uncoated 16-hour heated 300x magnification.

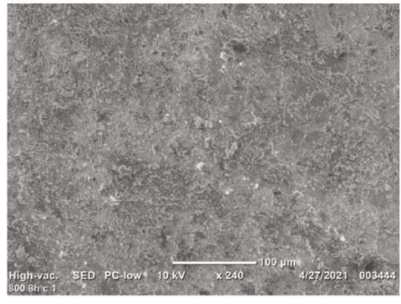

(a)

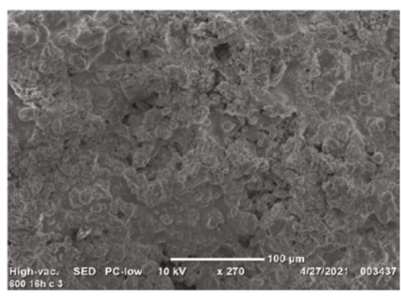

(c)

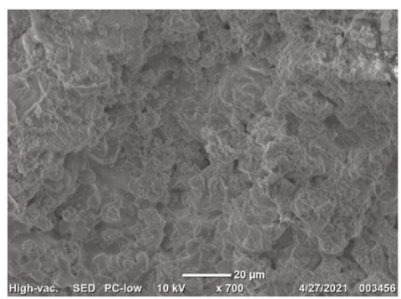

(e)

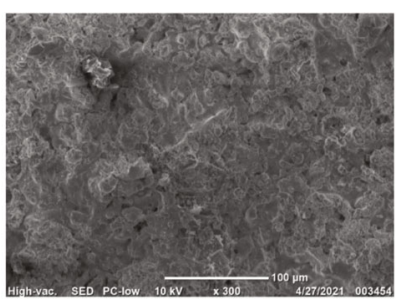

(b)

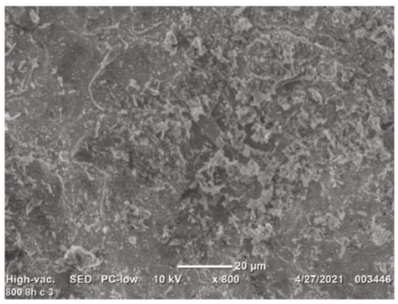

(d)

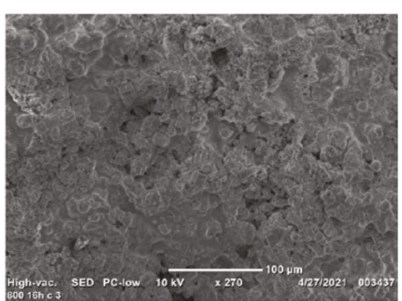

(f)

FIGURE 19: SEM images of Incoloy 800H specimens. (a) YSZ-coated 8-hour-heated 300x magnification. (b) YSZ-coated 12-hour-heated 300x magnification. (c) YSZ-coated 16-hour-heated 300x magnification. (d) YSZ-coated 8-hour-heated 300x magnification. (e) YSZcoated 12-hour-heated 300x magnification. (f) YSZ-coated 16-hour-heated 300x magnification.

images of the Inconel 625 specimens support the statement of YSZ-coated specimens are resisting the hot corrosion in a better manner comparing to the uncoated specimens. In the YSZ-coated specimens the formation of protective layer against the molten salt corrosion is evident on all 8-, 12-, and 16-hour-heated specimens. With reference to 


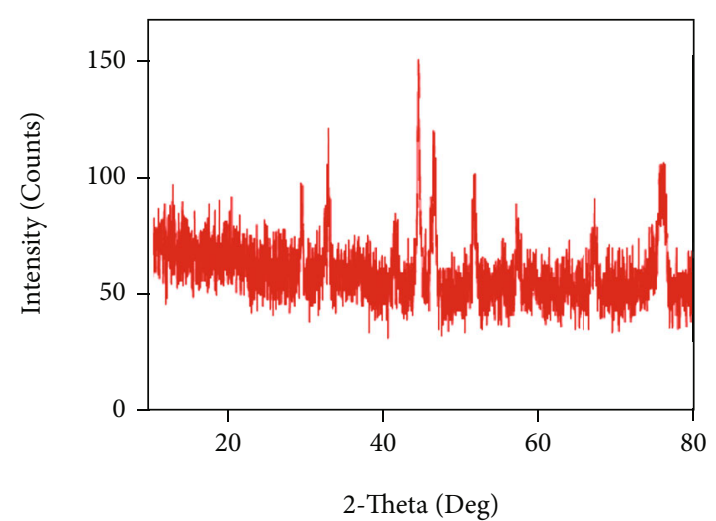

(a)

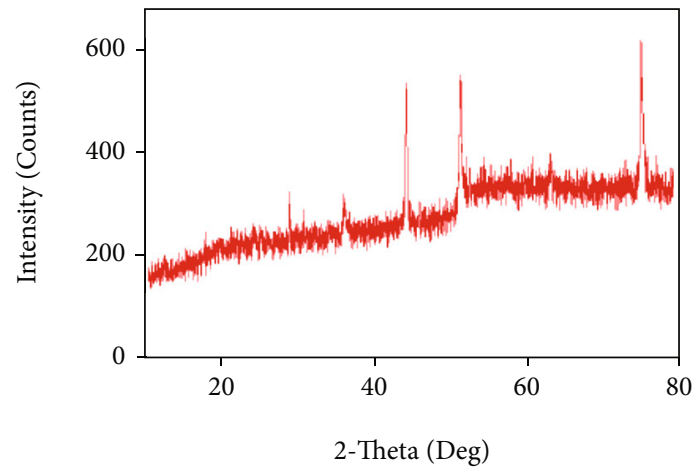

(c)

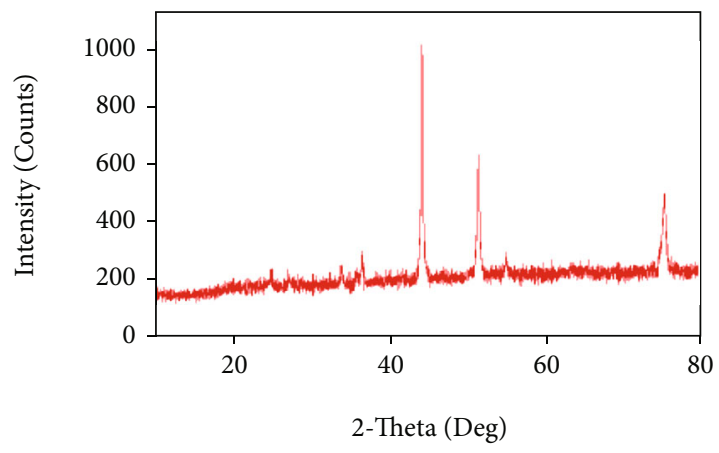

(e)

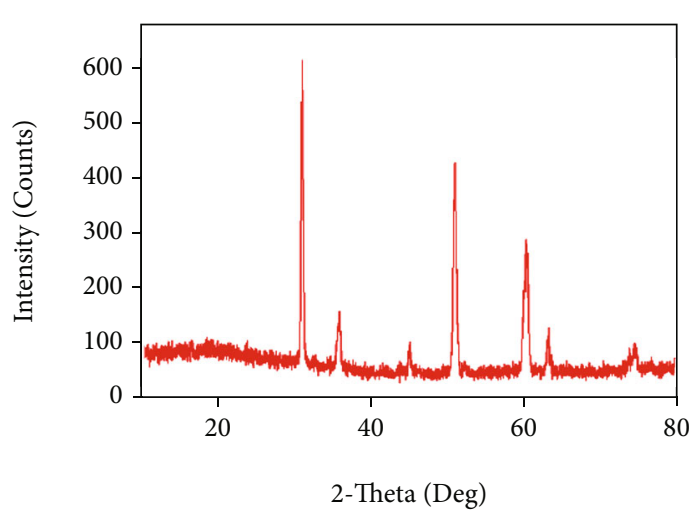

(b)

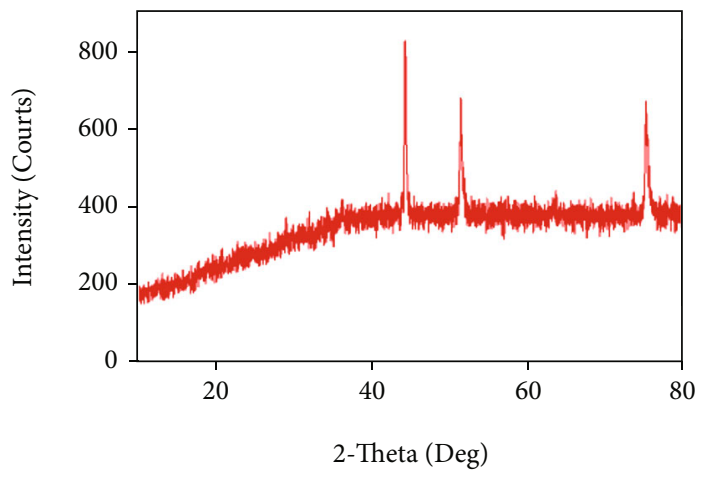

(d)

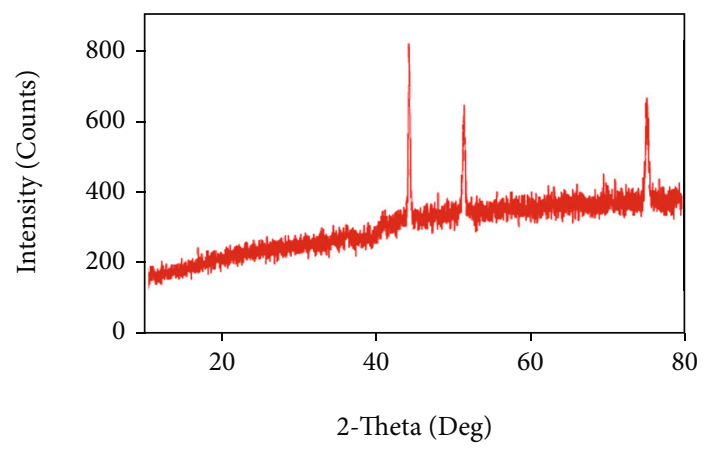

(f)

FIGURE 20: XRD results of Inconel 625 specimens. (a) Uncoated 8-hour-heated. (b) YSZ-coated 8-hour-heated. (c) Uncoated 12-hourheated. (d) YSZ-coated 12-hour-heated. (e) Uncoated 16-hour-heated. (f) YSZ-coated 16-hour-heated.

Figures 18 and 19, the SEM images of all heated Incoloy $800 \mathrm{H}$ uncoated and YSZ-coated specimens were taken in different magnification. The high-temperature corrosion is minimal in the YSZ-coated specimens on comparing with the uncoated specimens. The YSZ thermal barrier coating forms a protective layer and resists the corrosion formation on base substrate material.

3.5. XRD Analysis. The X-ray diffraction analysis is performed to study the microstructural properties of nickelbased superalloy specimens subjected to the hightemperature environment with chloride-based molten salts. The graph exhibits some XRD peaks of short- and long- range order and noise like pattern. But there are some very sharp peak points especially at 44.280 (2-theta deg) indicating the presence of crystalline structures. In YSZ-coated specimens, corrosion is not significant, and the crystal structures are present indicating that the atoms are placed in their lattice without getting disturbed from corrosion. In similar to the XRD graphs of Inconel 625 as shown in Figure 20, Incoloy $800 \mathrm{H}$ XRD graph as shown in Figure 21 also exhibits some all range of peaks. Here also are some very sharp peak points especially at 30.625(2-thetadeg) indicating the occurrence of crystalline structures. In coated specimens, corrosion is not substantial as the crystal structures are present without the atoms are rearranged. 


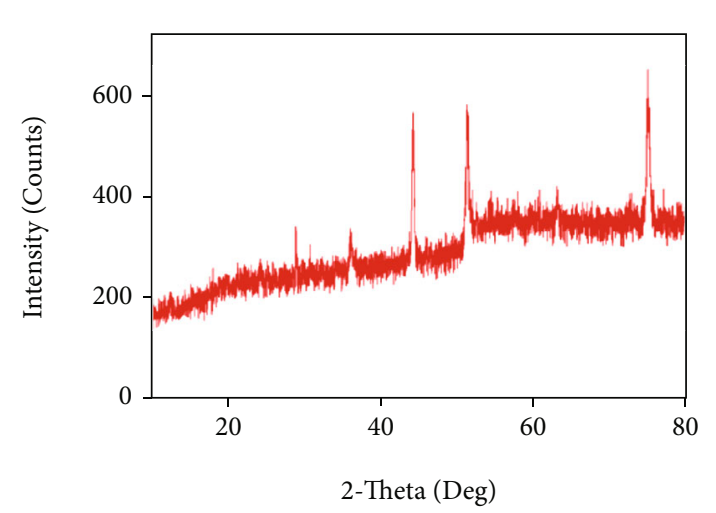

(a)

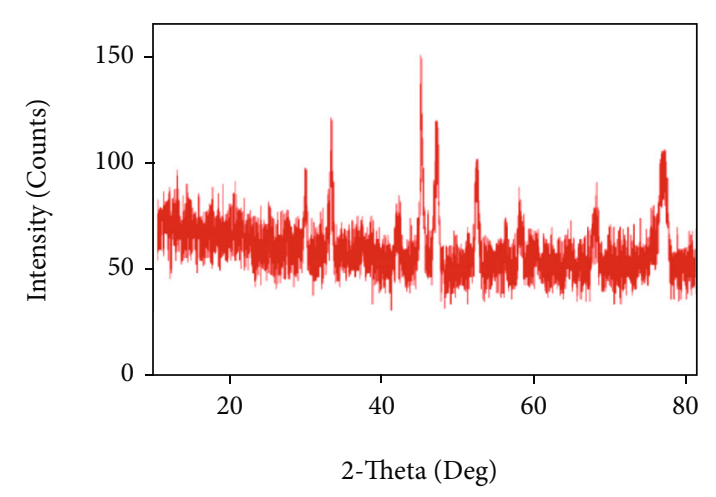

(c)

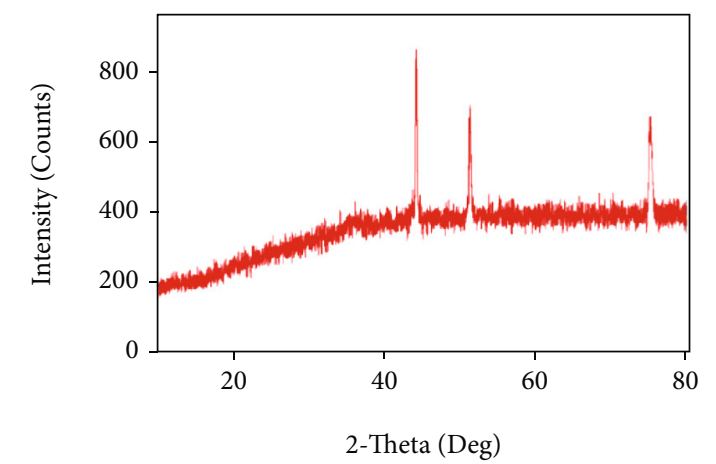

(e)

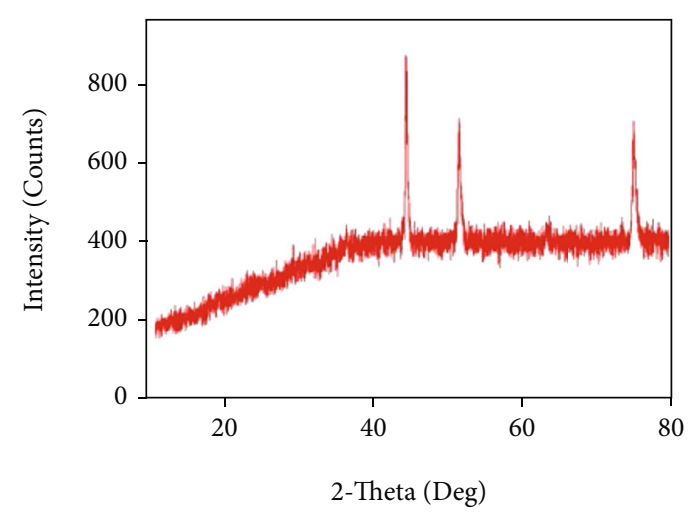

(b)

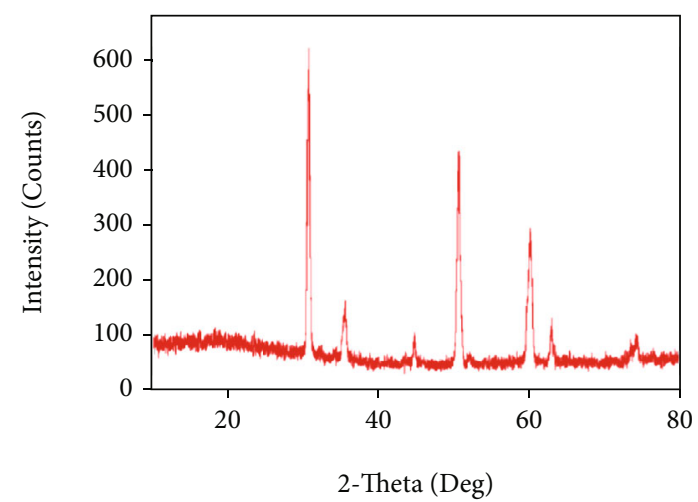

(d)

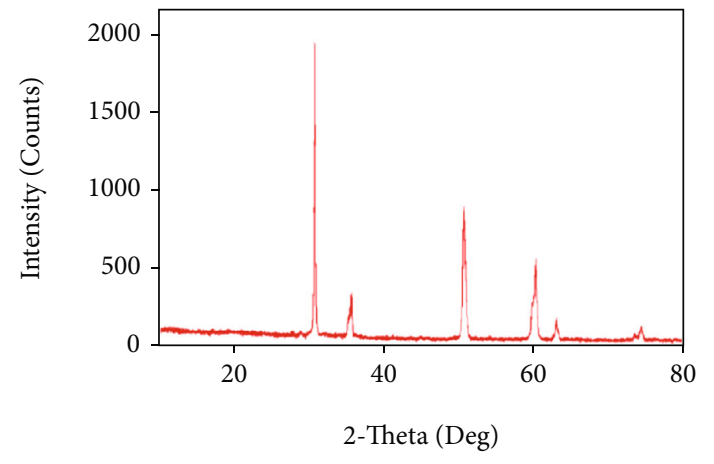

(f)

FIGURE 21: XRD results of Incoloy 800H specimens. (a) Uncoated 8-hour-heated. (b) YSZ-coated 8-hour-heated. (c) Uncoated 12-hourheated. (d) YSZ-coated 12-hour-heated. (e) Uncoated 16-hour-heated. (f) YSZ-coated 16-hour-heated.

\section{Conclusion}

The Inconel 625 and Incoloy $800 \mathrm{H}$ nickel-based superalloys were taken with molten salts such as sodium chloride and potassium chloride with a eutectic mixture of $7: 3$ for investigation. Yttria-stabilized zirconia-thermal barrier coating was coated on the alloy specimens to compare the mechanical and metallurgical properties of the raw specimen with the coated specimen.

To find the hot corrosion behaviour of the molten salts with the coated and uncoated alloy, the specimens were heated up to $1000^{\circ} \mathrm{C}$ for different hours. Tensile test and hardness test were performed to find the yield strength, ultimate tensile strength, and the \% of elongation and the hardness value.The SEM images and XRD analysis were performed to study the microstructural properties. Based on the experiments performed, the following recommendations were specified.

(i) Inconel 625 and Incoloy $800 \mathrm{H}$ are highly suited for to be used as storage material in the molten salts' thermal energy storage devices

(ii) Yttria-stabilized zirconia-thermal barrier coated alloy materials exhibit high strength and hardness 
and makes the alloy material as more corrosion resistant and temperature resistant. The statement is supported with the assistance of mechanical testing and microstructural analysis

For the future work, other superalloys with different thermal barrier coating types can be taken with the wide varieties of molten salts, and the hot-corrosion behaviour can be investigated.

\section{Data Availability}

All data used to support the findings of this study are included within the article.

\section{Conflicts of Interest}

The authors declare that they have no conflicts of interest.

\section{References}

[1] S. Bell, T. Steinberg, and G. Will, "Corrosion mechanisms in molten salt thermal energy storage for concentrating solar power," Renewable and Sustainable Energy Reviews, vol. 114, article 109328, 2019.

[2] S. Yuk, A. H. Azam, K. Miyanaga, and Y. Tanji, "The contribution of nitrate-reducing bacterium Marinobacter YB03 to biological souring and microbiologically influenced corrosion of carbon steel," Biochemical Engineering Journal, vol. 156, article 107520, 2020.

[3] G. W. MadjidSarvghad and T. A. Steinberg, "Study of the Microstructure and Cracking Mechanisms of Hastelloy X Produced by Laser Powder Bed Fusion," Solar Energy Materials and Solar Cells, vol. 11, no. 1, pp. 220-229, 2018.

[4] H.-z. Chen, B.-r. Li, B. Wen, Q. Ye, and N.-q. Zhang, "Corrosion resistance of iron-chromium-aluminium steel in eutectic molten salts under thermal cycling conditions," Corrosion Science, vol. 173, article 108798, 2020.

[5] A. Shamsipoora, M. Farvizia, M. Razavi, A. Keyvani, B. Mousavia, and W. Pan, "Hot corrosion behavior of thermal barrier coating on $\mathrm{Cr}_{2} \mathrm{AlC}$ and $\mathrm{CoNiCrAlY}$ substrates at $950^{\circ} \mathrm{C}$ in presence of $\mathrm{Na}_{2} \mathrm{SO}_{4}+\mathrm{V}_{2} \mathrm{O}_{5}$ molten salts," Surfaces and Interfaces, vol. 21, no. 2020, article 100679, 2020.

[6] Y. L. Wang, Q. Wang, H. J. Liu, and C. L. Zeng, "The effect of the microstructure on the corrosion behavior of N5 superalloy in a molten (Li,Na,K)F eutectic salt," RSC Advances, vol. 5, no. 41, pp. 32755-32760, 2015.

[7] A. Anderson, "Corrosion resistance of ceramic coatings sprayed on stainless steel substrates," International Journal of Ambient Energy, vol. 38, no. 3, pp. 320-322, 2017.

[8] A. Anderson and S. Ramachandran, "Analysis of corrosion at hot environment of plasma sprayed stainless steels," European Journal of Scientific Research, vol. 76, no. 2, pp. 300-308, 2012.

[9] W. Ding, A. Bonk, J. Gussone, and T. Bauer, "Electrochemical measurement of corrosive impurities in molten chlorides for thermal energy storage," Journal of Energy Storage, vol. 15, pp. 408-414, 2018.

[10] N. J. Harrison, I. Todd, and K. Mumtaz, "Reduction of microcracking in nickel superalloys processed by selective laser melting: a fundamental alloy design approach," Acta Materialia, vol. 94, pp. 59-68, 2015.
[11] F. Wang, "Mechanical property study on rapid additive layer manufacture Hastelloy ${ }^{\circledR} \mathrm{X}$ alloy by selective laser melting technology," The International Journal of Advanced Manufacturing Technology, vol. 58, no. 5-8, pp. 545-551, 2012.

[12] Y. Wang, H. Liu, G. Yu, J. Hou, and C. Zeng, "Electrochemical study of the corrosion of a Ni-based alloy GH3535 in molten $(\mathrm{Li}, \mathrm{Na}, \mathrm{K}) \mathrm{F}$ at $700{ }^{\circ} \mathrm{C}$," Journal of Fluorine Chemistry, vol. 178, pp. 14-22, 2015.

[13] L. S. I. Reddy, M. M. Vijayalakshmi, and T. Praveenkumar, "Thermal conductivity and strength properties of nanosilica and GGBS incorporated concrete specimens," Silicon, vol. 14, no. 1, pp. 145-151, 2022.

[14] S. Manigandan, T. R. Praveenkumar, and M. Amal, "Characterization of polyurethane coating on high performance concrete reinforced with chemically treated Ananas erectifolius fiber," Progress in Organic Coatings, vol. 150, article 105977, 2021.

[15] L. Romo, J. G. Gonzalez-Rodriguez, J. Porcayo-Calderon, R. Guardian, and V. M. Salinas-Bravo, "A study on the effect of $\mathrm{Co}, \mathrm{Cr}$ and $\mathrm{Ti}$ on the corrosion of FE40AL intermetallic in molten $\mathrm{NaCl}-\mathrm{KCl}$ mixture," Intermetallics, vol. 67, pp. 156$165,2015$.

[16] C. S. Sona, B. D. Gajbhiye, P. V. Hule et al., "High temperature corrosion studies in molten salt-FLiNaK," Corrosion Engineering, Science and Technology, vol. 49, no. 4, pp. 287-295, 2014.

[17] K. Vignarooban, P. Pugazhendhi, C. Tucker, D. Gervasio, and A. M. Kannan, "Corrosion resistance of Hastelloys in molten metal-chloride heat-transfer fluids for concentrating solar power applications," Solar Energy, vol. 103, pp. 62-69, 2014.

[18] A. A. Yaqoob, M. N. Ibrahim, and S. Rodríguez-Couto, "Development and modification of materials to build costeffective anodes for microbial fuel cells (MFCs): an overview," Biochemical Engineering Journal, vol. 164, article 107779, 2020.

[19] Y. V. Harinath, G. P. Reddy, T. K. Mohan, S. Rangarajan, and S. K. Albert, "Tensile behavior of Incoloy-800HT exposed to high-temperature molten FLiNaK salt and thermal aging," Journal of Materials Engineering and Performance, vol. 30, no. 11, pp. 8385-8394, 2021.

[20] H. V. Yadavalli, T. K. Mohan, S. Rangarajan, and S. K. Albert, "Design, fabrication, testing and operation of a simulation facility for high temperature molten salt studies," Journal of Engineering, Design and Technology, 2021. 